\title{
Leading Energy Performance Indicator: Tracking of Energy Management Systems in Oil and Gas Companies
}

\author{
Hashim K.M. ${ }^{1}$, Hassim Mimi H. ${ }^{1}$, Ng D.K.S. ${ }^{2}$ and Ten J.Y. ${ }^{1}$ \\ ${ }^{1}$ School of Chemical and Energy Engineering / Centre of Hydrogen Energy, \\ University Teknologi Malaysia, 81310 UTM Johor Bahru, Malaysia \\ ${ }^{2}$ School of Engineering and Physical Sciences, Heriot-Watt University, \\ No. 1, Jalan Venna P5/2, Precinct 5, 62200 Putrajaya Malaysia
}

\begin{abstract}
This paper presents a novel methodology that track and measures the overall energy performance in oil and gas companies based on the leading energy performance indicator (EnPI). Although such tool does not directly measure an actual and reflect an as-is operational data of the companies' energy performance, it tracks the achievements in the key work processes or the implementation status of an Energy Management Systems (EnMS). As introduced by the International Organization for Standardization (ISO) in 2011, EnMS consists of interacting elements from proven deployment and implementation steps based on the Plan-Do-Check-Act (PDCA) continual improvement framework. The lacks of industrial standards and literature have resulted in the sparse application of leading EnPI. The proposed leading EnPI tool is based on the defined activities that affect the deployment and implementation of EnMS. Such tool is required for continuous improvement and promotion of strong partnership among all stakeholders. To illustrate the proposed methodology, the progress of EnMS implementation, identification of energy-saving initiatives, and review of potential energy savings of the major oil and gas companies are performed.
\end{abstract}

Keywords: leading energy performance indicator (EnPI); Energy Management Systems; energy performance

\section{INTRODUCTION}

Energy Management Systems (EnMS) is a set of interrelated or interacting elements of an organisation to establish energy policies from identified visions as well as to develop steps (e.g., defining and tracking energy performance indicators (EnPIs)) to achieving the defined objectives (ISO50001, 2018). According to the International Petroleum Industry Environmental Conservation Association (IPIECA), EnMS is a preferred management framework (IPIECA, 2013a) to assist oil and companies in excelling in energy performance. The first revision of EnMS was released by International Organization for Standardization
(ISO) in June 2011. EnMS enables the oil and gas companies to follow a systematic approach in achieving continual improvement of energy performance (i.e., energy efficiency, energy supply security, energy use and consumption) (ISO50001, 2018).

One of the important steps of EnMS is to establish EnPIs (Hassim et al., 2018). EnPIs assist oil and gas companies in gauging their overall EnMS implementation against ISO 50001expectations as well as desired performance targets. Therefore, dedicated actions can be taken to correct them. EnPIs will ensure common objectives of EnMS (e.g., increase reputation, improve energy intensity, reduce cost and greenhouse gas (GHG) emission) are met (Nuaim, 
2019). Based on IPIECA (2013b), two types of EnPIs are introduced, which are leading and lagging.

Most of the oil and gas companies that applied lagging EnPIs are based on actual operational data that reflect the as-is situation of energy performance (IPIECA, 2013a). A basic measure of lagging EnPI is also known as Energy Intensity (EI) or Energy Utilization Index (EUI) in industry and building respectively. EI is a measure of the energy required in generating a unit of product (Solomon, 2013). Meanwhile, EUI is a measured value of the amount of energy annually used for cooling or heating a building or facility per area of conditioned space (Turner, 2001).

Lagging EnPI is based on actual operational data which reflects an organisation's energy performance at the time of data collection (Vanner, 2013). It is noted that lagging EnPI refers to past achievement (ISO 50006, 2014). The application of lagging EnPI is common and essential to the global economy for decades to come in most of the prominent oil and gas companies (Parmenter, 2007). Note also that lagging EnPI has been effectively applied in many Japanese companies for decades in managing uncertainty in the energy supply chain (Imai, 1986).

On the other hand, leading EnPI provides overall progress in driving for continuous improvement in the energy performance (The Arabian Sun, 2014). Marcus (2011) indicated that leading EnPI is a preferred tracking tool to monitor the progress of continuous improvement in overall energy performance, tracking performance scorecard and reporting results of EnMS implementation. Estes (2009) suggested that leading EnPI can be applied to monitor the progress against the implementation objectives of EnMS in which companies are deployed. In some cases, progress is defined by the achievement made towards milestones, but often, it is simply the repeated achievement of some levels of operational objectives and targets. However, the application of leading EnPI is still in the early stage (DNV, 2015). Kumana and Sidhwa (2009) addressed that there is no accepted industry standard for developing a leading EnPI. Although the proposed concept is simple, the actual implementation of a company-wide monitoring program is usually fraught with challenges, many of which are often political and cultural rather than technical (Kumana and Sidhwa, 2009).

\section{A. Leading Energy Performance Indicator}

The introduction of leading EnPI is believed to support and extend the idea of continuous improvement (Parmenter, 2007). Despite several claims to the application of leading EnPI in boosting productivity, lowering down energy utilisation and reducing environmental footprint at concerned oil and gas companies, the revealed information details are scarce (Schuster, 2015). It appears that the leading indicator has yet to be fully adapted to measure energy performance as there is no literature that describes any successful application in major oil and gas companies (Kumana and Sidhwa, 2009). In addition, limited works have focused on the implementation of leading EnPI, especially in oil and gas industry. Thus, newly established methodology shall be explored to determine its flexibility as well as effectiveness to drive for improving the overall energy performance. On the other hand, the leading indicator application is not new as there are a number of non-oil and gas companies that have measured their business achievements other than energy performance for decades. Table 1 summarises the prominent international companies that utilise leading indicators to predict their business sustainability.

Table 1: Leading indicators for selected companies (Parmenter, 2007)

\begin{tabular}{|c|c|c|}
\hline Company & Leading indicators & Method of measure \\
\hline 3 M Corp & $\begin{array}{l}\text { - } \\
\text { innovations } \\
\text { - } \\
\text { - } \\
\text { Pumber of new patents } \\
\text { satisfaction }\end{array}$ & $\begin{array}{l}\text { - Establish a baseline for each identified indicator } \\
\text { - Define challenging targets based on external } \\
\text { benchmarking against competitors } \\
\text { - Collect data at a defined frequency } \\
\text { - Analyse data and define gaps }\end{array}$ \\
\hline
\end{tabular}




\begin{tabular}{|c|c|c|}
\hline & & - Plan actions to close gaps \\
\hline Dell Computer & $\begin{array}{l}\text { - } \\
\text { Percentage of customer } \\
\text { - } \quad \text { Supplisfaction in inventory }\end{array}$ & $\begin{array}{l}\text { - Explore how other competitors tracking their } \\
\text { customer satisfaction } \\
\text { - Define current status and future targets } \\
\text { - Establish a data collection mechanism } \\
\text { - Collect and analyse data and define gaps } \\
\text { - Plan actions to close gaps }\end{array}$ \\
\hline Coca-Cola & $\begin{array}{l}\text { Brand growth due to } \\
\text { sustainability efforts }\end{array}$ & $\begin{array}{l}\text { - Determine best practices from other businesses } \\
\text { - Collect and analyse data and define gaps } \\
\text { - Plan actions to close gaps }\end{array}$ \\
\hline
\end{tabular}

One of the national oil and gas companies in the Middle East has initiated the effort to define suitable leading indicator to measure its overall energy performance (The Arabian Sun, 2015a). The company has reported using a leading EnPI by measuring its EnMS implementation progress. It includes; identifying and implementing energy savings initiatives, reporting energy performance, conducting energy efficiency awareness and tracking energy action items. However, it is still preliminary as there is no further update on the practicality and effectiveness of the initiative (The Arabian Sun, 2015a).

Note that Energy Star (2016) has an established assessment matrix to measure companies' performance in meeting critical elements of EnMS. The matrix can be considered as a preliminary step of leading indicator. It can be used as a checklist to ease the self-assessment team in tracking the progress of several leading elements, including responsibilities, awareness events and also continuous improvement efforts. However, this is a readiness review to prepare companies for ISO 50001 certification, and there is no repetition in this activity. The concept of leading EnPI is beyond the typical qualitative approach of achieving the EnMS certification, but it provides a qualitative indicator to gauge the status of achievement (Hassim et al., 2018). The leading EnPI provides a tool to measure whether the company is progressing towards becoming an excellent company. Even though many oil and gas companies have gained EnMS certification, some of them are still at a slow pace to reach for excellence in energy performance. It appears that their main focuses are cost reduction, reputation and then energy consumption respectively (DNV, 2015). According to Organization for Economic Cooperation and Development (OECD), the concerned oil and gas companies are lacked strategic development and execution on EnPI monitoring, corrective and preventive action, and continuous improvement efforts (OECD, 2015).

Implementation of EnMS provides the opportunity to establish leading indicators such as monitoring the achievements in implementing the respective EnMS' steps or sub-steps, level of management supports or compliance status (IPIECA, 2013a). Leading EnPI tends to communicate change in environmental practices such as renewable energy projects, innovations, achievements and other related activities (Parmenter, 2007). Hassim (2018) indicated that EnPI impels a strong focus on progress tracking through join coordination with other organisation initiatives such Environment Management Systems (EMS), Operational Excellence Systems (OES) or Total Preventive Maintenance (TPM). However, most oil and gas companies are not doing well in terms of tracking the level of implementation progress and efforts of continuous improvement.

This paper presents a newly developed methodology based on a well-established leading EnPI for tracking the status of EnMS implementation in oil and gas companies. Besides, step by step actions based on a proven methodology to establish and implement applicable leading indicator to monitor energy performance are discussed. It assists the company in achieving full implementation of EnMS by providing comprehensive monitoring progress of EnMS implementation. This methodology can also be applied by companies or organisations other than oil and gas sectors for effective implementation and deployment of EnMS. 


\section{METHODOLOGY}

Figure 1 provides a brief methodology of this whole concept, as presented in this paper. The main objective is to select the appropriate leading EnPI methodology for the concerned oil and gas companies. The leading EnPI methodology must be practicable, user-friendly and can push for continuous improvement. It also includes a method to define realistic baselines and targets that can induce EnMS implementation status and drive to ultimate energy efficiency performance.

Firstly, surveys or interviews are conducted to define expectations from various parties (e.g., collection of organisations' energy visions, strategies and methods of performance tracking). This step is intended to conclude organisations stand on the following subjects; overall EnMS commitment, method of tracking the EnMS implementation progress and ongoing effort to improve energy performance. In this case, a survey will be initiated on more than 30 facilities from an anonymous national oil and gas company. The survey aims to understand respondents' views on EnMS, especially EnPI so that necessary challenges can be identified. Subsequently, the second survey will be conducted to figure out common approaches to mitigate all those challenges.
It follows by collecting relevant lessons learned from industries pamphlets, annual reports, company websites, magazines, literature and journals as ways to define expectations on EnPI, especially leading indicators. Collected information will be reviewed to find their rationales. This information will be referred in defining an applicable leading EnPI for oil and gas companies.

Subsequently, a selected leading EnPI methodology is piloted as a case study at one of the oil and gas companies. The associated tasks before fulfilling this step are as follows;

- Coordinating case study that involves gathering organisation buy-in, conduct training and awareness, assist deployment and implementation of preferred EnMS and engage in self-assessment exercises.

- Managing self-assessment data that comprises of data collection, review and validation.

- Reporting findings that include defining conclusion, way forward endorsement, and presentation.

Finally, the outcomes from the case study will be closely reviewed to capture lessons learned. Detail description of the case study is presented in Section 3.3.

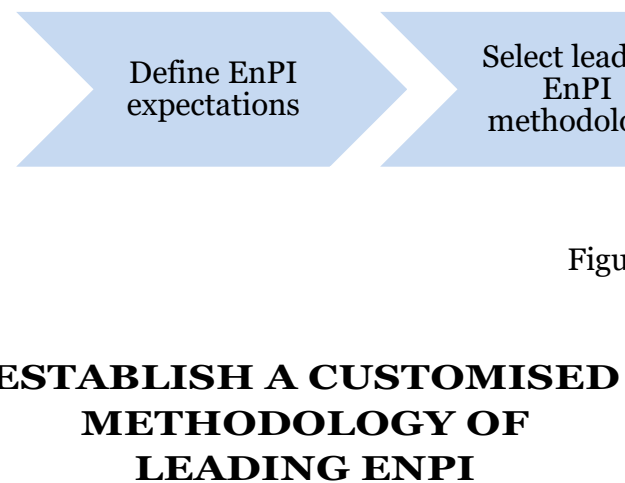

The following sub-titles will describe the detailed mechanisms to establish and deploy of the leading EnMP as a tool to track the implementation of EnMS in oil and gas companies. It follows with a case study at one of the leading oil and gas companies.

\section{A. Identify Suitable EnPI}

Two surveys were completed on more than 30 facilities from an anonymous national oil and gas company. The outcomes from these surveys were evaluated to define the need for special focus on leading EnPI. The findings of common expectations, challenges and mitigations in implementing EnMS are listed in Table 2.

The major finding from the surveys related to EnPI is the need to establish a simple and measurable leading indicator before driving towards continuous improvement in energy performance. The selected methodology for leading EnPI shall be simple and easy to be implemented without the need for massive resource allocation. It also provides simple overview on the level of EnMS implementation of any concerned company against its standard requirements such as international standards' EnMS (ISO 50001, 2018), 
Superior Energy Performance (Energy Star, 2016) or any other internal guidelines.

With well-defined implementation milestones, the actual status of EnMS implementation can be determined. Subsequently, any gap to achieve the desired targets can be identified. The selected leading indicator should ensure for a fair presentation, comprehensive and professionally derived which can assist applicable organisations in mitigating all identified lapses in addressing the expectation of EnMS as well as agreeable objectives and targets.

Table 2: List of challenges, mitigations and identified strategies

\begin{tabular}{|c|c|c|}
\hline $\begin{array}{c}\text { Expectations and } \\
\text { challenges (based on } \\
\text { Survey } 1 \text { and 2) }\end{array}$ & $\begin{array}{c}\text { Mitigations } \\
\text { (based on Survey 2) }\end{array}$ & Recommended strategies \\
\hline $\begin{array}{l}\text { Set clear corporate } \\
\text { direction }\end{array}$ & $\begin{array}{l}\text { - Establish comprehensive EnMS visions and } \\
\text { - } \text { Identicies } \\
\text { to relevant focus areas } \\
\text { - Strengthen EnMS governance } \\
\text { - Define EnPI and conduct regular } \\
\text { monitoring task } \\
\text { - Develop EnMS with the main objective to } \\
\text { improve EnPIs } \\
\text { - Embed EnMS into existing management } \\
\text { programs } \\
\text { - Establish relevant standards and policies } \\
\text { Check applicability of the EnMS to its } \\
\text { company }\end{array}$ & $\begin{array}{l}\text { - Follow energy policy checklist and } \\
\text { indicate a clear link to respective } \\
\text { focus areas } \\
\text { - Gather commitment from } \\
\text { management through regular } \\
\text { performance update } \\
\text { - Gain momentum with other } \\
\text { matured programs } \\
\text { - Adopt the right EnPIs which } \\
\text { provides; simplicity to users and } \\
\text { acceptable leading indicators } \\
\text { Establish applicability checklist }\end{array}$ \\
\hline EnPIs establishment & Define the scope of coverage & $\begin{array}{l}\text { Establish lagging and leading } \\
\text { indicators }\end{array}$ \\
\hline Enhance Competency & $\begin{array}{l}\text { - Define relevant competency requirement } \\
\text { Engage adequate resources; training } \\
\text { facilities, train the trainer course, budget } \\
\text { allocation and others }\end{array}$ & $\begin{array}{l}\text { - Develop a list of recommended } \\
\text { courses } \\
\text { - Include detailed qualification of } \\
\text { critical EnMS positions in the } \\
\text { framework }\end{array}$ \\
\hline $\begin{array}{l}\text { Energy data analysis, } \\
\text { monitoring, corrective and } \\
\text { preventive }\end{array}$ & $\begin{array}{l}\text { - Identify EnPIs for significant energy users } \\
\text { (SEUs) } \\
\text { - Ensure SEUs performances are tracked } \\
\text { - Conduct an internal audit }\end{array}$ & 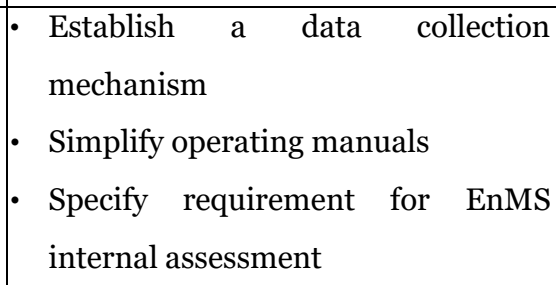 \\
\hline
\end{tabular}

Data were collected from literature to fulfil the required tasks as specified by Section 2. It started with initial findings as listed in Table 3, which provide a list of companies and countries that established EnPIs based on their needs and applicability. After reviewing and analysing their practices in monitoring the energy performance, it appears that they are lacking leading EnPI. 
Inline to assess the overall progress of EnMS implementation for any concerned companies, the methodology for leading EnPI shall be established in such to provide an overview of its continuous improvement progress toward becoming an excellent company in energy performance (Tucker, 2002). This methodology shall be customised for monitoring implementation progress of each step from its adopted EnMS. It includes but not limited to energy visions understanding, effectiveness of energy analysis, objectives and targets tracking, EnPIs monitoring, competency training and identifying opportunity. In addition, this methodology has to be formulated to track its continuous improvement tasks. It includes; gaining adequate supports from management, publishing of best practices, generation of energy savings ideas, participation in communities of practices (CoP), training conducted and other related activities (ISO 50001, 2015).

Table 3: Methodology applied by leading companies and countries on EnPIs

\begin{tabular}{|c|c|c|}
\hline Company name & Performance focus & EnPI \\
\hline $\begin{array}{l}\text { Shell production facilities } \\
\text { (Shell, 2013) }\end{array}$ & $\begin{array}{l}\text { - Monitor energy performance } \\
\text { - Benchmark refinery performance }\end{array}$ & $\begin{array}{l}\text { Energy consumed over a ton of } \\
\text { product } \\
\text { - Solomon Energy Intensity Index } \\
\text { (EII) }\end{array}$ \\
\hline $\begin{array}{l}\text { British Petroleum (BP) } \\
\text { production facilities (BP, 2012) }\end{array}$ & $\begin{array}{l}\text { - Monitor energy performance } \\
\text { - Benchmark its similar type of } \\
\text { operation facilities }\end{array}$ & Energy consumed over a ton of product \\
\hline $\begin{array}{l}\text { Saudi Aramco (Saudi Aramco, } \\
\text { 2015) }\end{array}$ & Monitor energy performance & Energy over barrel oil equivalent \\
\hline Exxon Mobil (IPIECA, 2013b) & $\begin{array}{l}\text { - Benchmark refinery and other } \\
\text { petroleum facilities performance } \\
\text { - Monitor energy performance for } \\
\text { each particular operation facility } \\
\text { (benchmark) }\end{array}$ & $\begin{array}{l}\text { - Solomon EII } \\
\text { Energy consumed over } \\
\text { ton of product }\end{array}$ \\
\hline BASF (BASF, 2013) & $\begin{array}{l}\text { Monitor energy performance and } \\
\text { conduct benchmark }\end{array}$ & A ton of product over energy consumed \\
\hline TOTAL OIL (IPIECA, 2013b) & $\begin{array}{l}\text { Monitor energy performance and } \\
\text { benchmark }\end{array}$ & Energy over a ton of product \\
\hline $\begin{array}{l}\text { US’s Environmental Protection } \\
\text { Agency (Energy Star, 2016) }\end{array}$ & $\begin{array}{l}\text { Benchmark refinery and other } \\
\text { petroleum facilities performance } \\
\text { - Other industries using energy } \\
\text { performance }\end{array}$ & $\begin{array}{l}\text { - Solomon EII } \\
\text { - Energy over product }\end{array}$ \\
\hline $\begin{array}{l}\text { Dutch Government (covenant } \\
\text { goal) (IPIECA, 2013b) }\end{array}$ & Measure refinery performance & Solomon EII \\
\hline $\begin{array}{l}\text { Japanese Government (Energy } \\
\text { Star, 2016) }\end{array}$ & Measure refinery performance & Solomon EII \\
\hline $\begin{array}{l}\text { New Zealand Government } \\
\text { (Energy Star, 2016) }\end{array}$ & Measure refinery performance & Solomon EII \\
\hline
\end{tabular}

According to the Arabia Sun (2015b), one of the Middle Eastern oil and gas companies has started to link its EnPI to
EnMS implementation, which is believed to provide an excellent starting point to develop the proposed leading 
EnPI indicator. This company has revealed some of the tracking clues:

- Implementation status of energy conservation initiatives.

- Energy performance trends such as energy efficiency by product, process unit and major equipment.
- Energy objectives and targets the status of achievement.

- $\quad$ Effectiveness of operational and maintenance activities to enhance energy efficiency.

- Level of awareness among the companies' management and employees.

Table 4: Comparison of other leading indicators

\begin{tabular}{|c|c|c|c|c|}
\hline Type of leading EnPI & Comprehensiveness & $\begin{array}{c}\text { Reliable to } \\
\text { describe the } \\
\text { status of EnMS } \\
\text { implementation }\end{array}$ & Sustainable & Cost-effective \\
\hline Proposed Leading EnPI & $\begin{array}{l}\text { Yes, covers for whole PDCA } \\
\text { elements and other } \\
\text { organisation expectations }\end{array}$ & $\begin{array}{l}\text { Yes, provides an } \\
\text { actual status of } \\
\text { EnMS } \\
\text { implementation }\end{array}$ & $\begin{array}{l}\text { Yes, it can be } \\
\text { done by the } \\
\text { organisation } \\
\text { itself }\end{array}$ & $\begin{array}{l}\text { Yes, no } \\
\text { associated cost }\end{array}$ \\
\hline $\begin{array}{l}\text { Energy Star assessment } \\
\text { matrix (Energy star, } \\
\text { 2016) }\end{array}$ & $\begin{array}{l}\text { No, covers only fragmented } \\
\text { focuses such as } \\
\text { responsibilities, awareness } \\
\text { program and also } \\
\text { continuous improvement } \\
\text { efforts }\end{array}$ & $\begin{array}{l}\text { No, provides only } \\
\text { based on fragmented } \\
\text { samples of selected } \\
\text { focus areas }\end{array}$ & $\begin{array}{l}\text { Yes, it can be } \\
\text { done by the } \\
\text { organisation } \\
\text { itself }\end{array}$ & $\begin{array}{l}\text { Yes, no } \\
\text { associated cost }\end{array}$ \\
\hline $\begin{array}{l}\text { EnMS certification (ISO } \\
50001,2018)\end{array}$ & $\begin{array}{l}\text { Yes, covers only an annual } \\
\text { event as well as random } \\
\text { samples }\end{array}$ & $\begin{array}{l}\text { No, provides a pass } \\
\text { or fail }\end{array}$ & $\begin{array}{l}\text { No, it has to be } \\
\text { done by } \\
\text { certified } \\
\text { companies }\end{array}$ & $\begin{array}{l}\text { No, requires } \\
\text { certification fee }\end{array}$ \\
\hline
\end{tabular}

The customised leading EnPI shall be based on an allocated weight for each of the major EnMS elements as per Deming quality cycle of Plan-Do-Check-Act (PDCA) (IPIECA, 2013b). Certain weights have been given to reflect on the current needs of each concerned company. The maximum weight of $100 \%$ shall be allocated to a company that fully met all the agreed expectations. Allocation for PDCA may be different; for example, during early stage of EnMS implementation, the Plan stage shall have the highest weight. As the program progresses, the Do and Check shall be given the highest weight. Once the program is matured, the Act stage shall obtain the highest weight in order to ensure continuous improvement concept is fully embraced by the concerned companies. Descriptions of each EnMS step are as follows;
Plan:Establish energy policy, conduct energy analysis, define objectives and targets, develop and communicate energy plans, assign functions and responsibilities.

Do: Enhance awareness and competency, conduct energy analysis, identify energy focus, gather and evaluate energy efficiency initiatives.

Check: Collect and assess all relevant energy data, implementation records, as well as EnMS implementation.

Act: Conduct management review, recognise achievement and gather feedbacks for enhancing its program. 
The proposed EnPI is unique as it covers the whole elements of PDCA, other critical expectations of EnMS as well as organisations objectives and targets. Table 4 provides a brief comparison to two other popular leading EnPI methodologies, which mainly focus on fragmented areas of interests or even based on random samples. The proposed EnPI provides reliable source of information on EnMS implementation status at any given time. It also identifies gaps before meeting the desired objectives and targets. In addition, it can be executed without any associated cost and third party's engagement.

\section{B. Deployment of Leading EnPI}

The deploying methodology of leading EnPI applied in this paper is based on reputable references such as Energy Star (Energy Star, 2016), actual site application as well as a relevant ISO standard (ISO 50006, 2014). Actual site application will be discussed in the case study (Section 3.3). In order to deploy the selected leading EnPI, it involves a number of implementation steps. Figure 2 illustrates the overview of the proposed methodology to cover for Deming PDCA quality cycle.

It starts with the establishment of activities list from applicable steps and related sub-steps as per reputable EnMS such as ISO 50001. Figure 3 illustrates the example of steps and sub-steps of EnMS that are commonly applied as leading drivers for continuous improvement in energy performance. Subsequently, the applicable list of essential energy-related tasks that aim for continuous improvement can be selected. As reference, Table 5 provides list of typical tasks applied by oil and gas companies and its selection rationales (IPIECA, 2013a). The selection of leading drivers is reliant upon definition of what is important to the company.

While selecting a leading EnPI, it needs to match with applicable company defined objectives and targets. This is important for establishing significant EnMS' milestones and their baselines. Therefore, realistic leading EnPI targets can be determined. Depending on the selected EnPI, it may require performing activities such as series of data collection, interviews, assessment, data analysis and verification. Finally, a performance review with the management can be conducted. Any feedback gathered from the review will be considered to improve the implementation of EnMS.

In order to meet the intent of this paper, which focuses on simplification, practical and easy to implement, the simple self-assessment approach shall be selected. A case study on the actual implementation of tracking the leading EnPI for an oil and gas company will be compiled as reference.

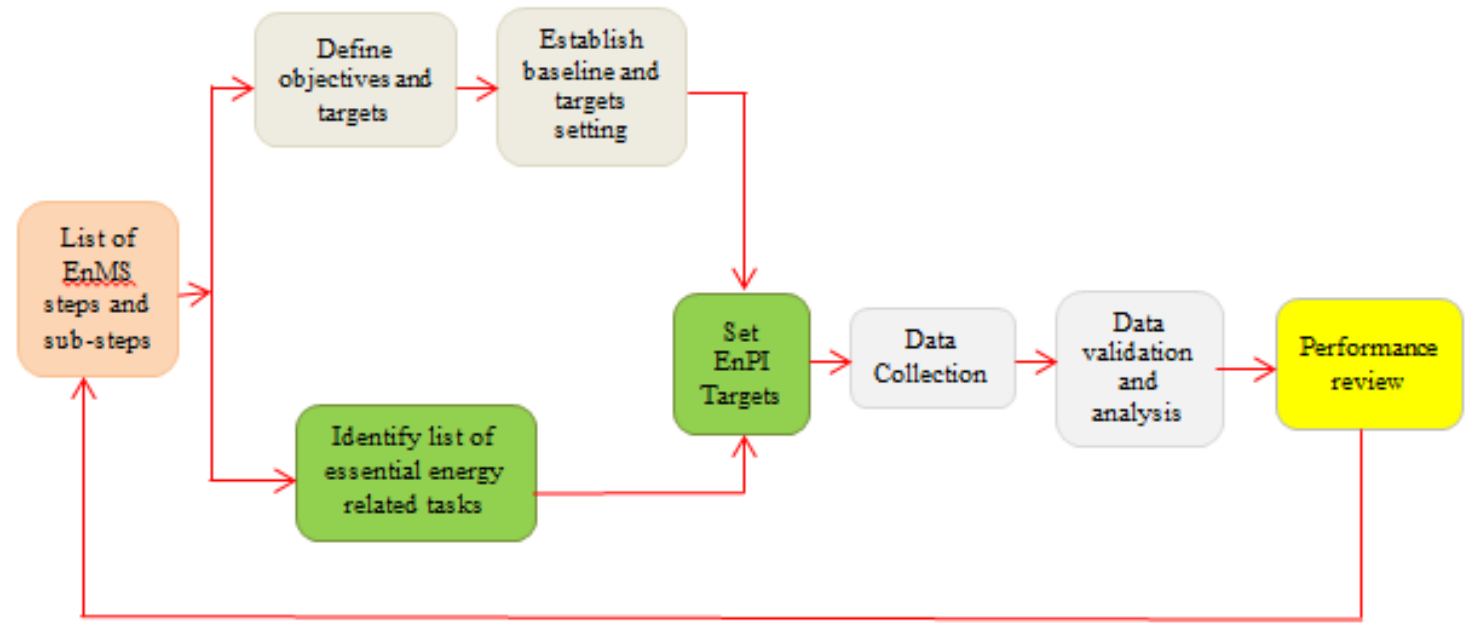

Figure 2: Leading EnPI deployment steps 

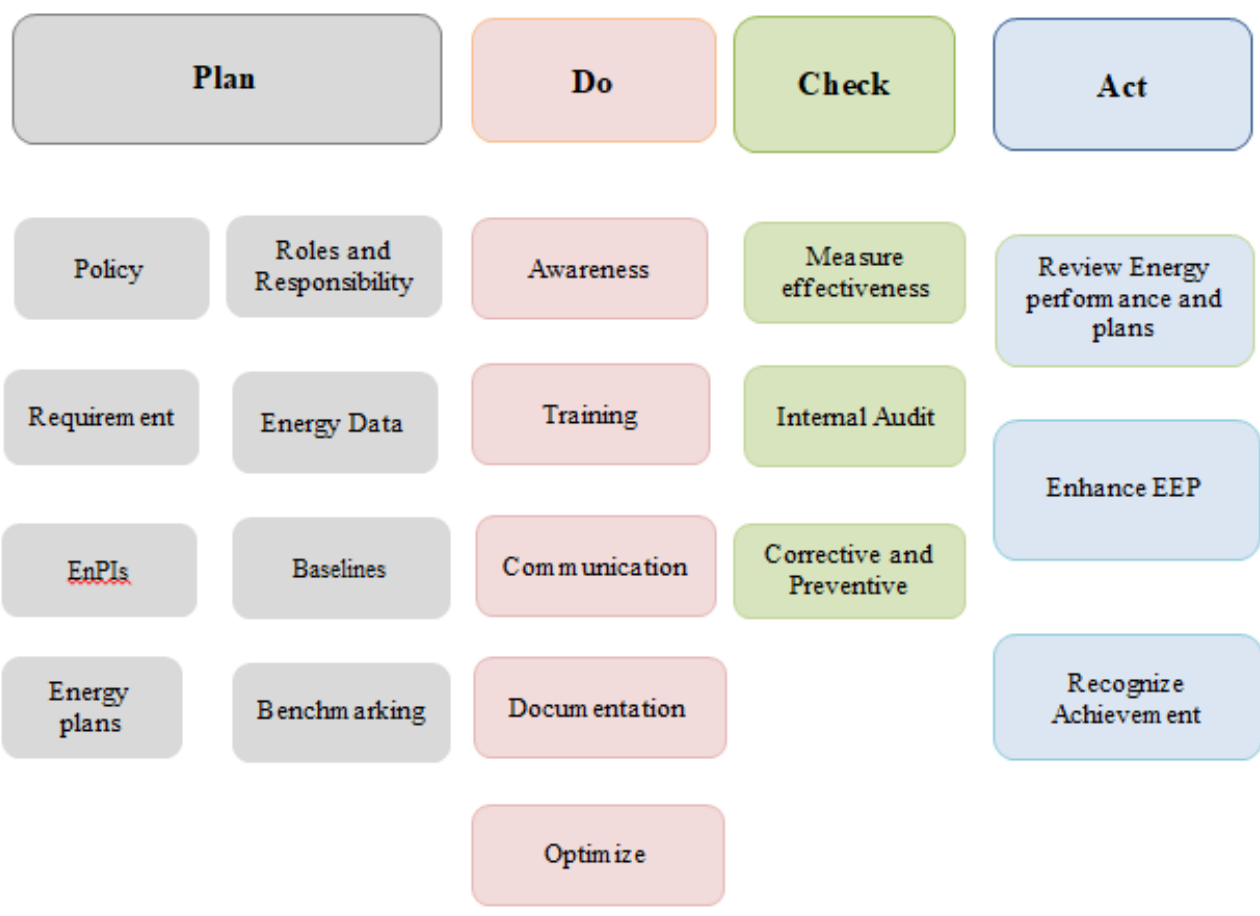

Review Energy perform ance and plans

Enhance EEP
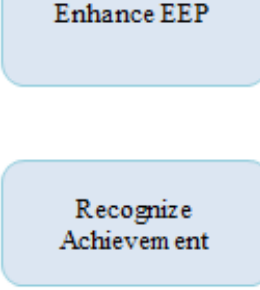

Figure 3: Typical steps of EnMS (Hassim et al. 2018)

Table 5: Typical list of essential energy-related tasks

\begin{tabular}{|c|l|l|}
\hline No & \multicolumn{1}{|c|}{ Task description } & \multicolumn{1}{|c|}{ Rational } \\
\hline 1 & Number of energy assessment completed & Provide a level of company commitment \\
\hline 2 & Energy savings initiatives identified & Efforts to improve energy performance \\
\hline 3 & Amount of potential energy savings reviewed & Efforts to improve energy performance \\
\hline 4 & Initiatives translated into projects & Effectiveness of energy optimisation \\
\hline 5 & $\begin{array}{l}\text { Percentage of completed energy performance } \\
\text { benchmarking }\end{array}$ & Efforts to improve energy performance \\
\hline 6 & Energy best practices issued. & Lessons learned efforts \\
\hline 7 & $\begin{array}{l}\text { Percentage of implementation of energy } \\
\text { conservation initiatives }\end{array}$ & Efforts to improve energy performance \\
\hline 8 & Number of conducted training and & Efforts to enhance energy implementation \\
\hline 9 & awareness & Efforts to improve energy performance \\
\hline 10 & Number of certified energy manager & Efforts to improve energy performance \\
\hline 11 & Implementation progress of EnMS & Identify implementation gaps \\
\hline
\end{tabular}

\section{Define Energy Baseline and Target for Leading EnPI}

The understanding of current and future direction in selected leading EnPI is one of the critical tasks prior to identifying opportunities to improve energy performance and gain financial benefits (BP, 2012; Energy Star, 2016). Performance assessment is the periodic process of evaluating its implementation progress within any applicable function and task in the company. Therefore, establishing solid baselines for measuring future results of ongoing efforts is essential. The success of an EnMS depends on continuous examining of its performance using the PDCA cycle. When it comes to measuring progress toward these elements, though, the best way to monitor it is with the use of energy management metrics. There are 
numerous methods, strategies, and key metrics that companies may use for analysing and benchmarking energy performance. However, the most appropriate approach is to evaluate the EnMS implementation progress against certain targets such as the minimum requirement defined by relevant ISO standards (ISO 50001, 2018; ISO 50006, 2014) or implementation tasks as per Table 5 .
The target score depends on specific site condition, methodology, visions, baselines and current progress status. The list of example baselines and target set are described in Table 6. It can be extended to include other dimensions such as energy-saving generated, patents compiled, and recognitions received.

Table 6: Example of baselines and targets setting

\begin{tabular}{|c|c|c|c|}
\hline No & Task description (Measure) & Baseline & Target \\
\hline 1 & EnMS' PDCA elements & $\begin{array}{l}\text { Meeting ISO 50001' minimum } \\
\text { requirement }\end{array}$ & $25 \%$ for each PDCA element \\
\hline 2 & $\begin{array}{l}\text { Number of energy assessment } \\
\text { completed }\end{array}$ & $\begin{array}{l}\text { Two assessments per year based on } \\
\text { historical data }\end{array}$ & $\begin{array}{l}\text { Five assessment per year based } \\
\text { on industry best practice }\end{array}$ \\
\hline 3 & Energy savings initiatives identified & $\begin{array}{l}20 \text { initiatives per year based on } \\
\text { previous years }\end{array}$ & $\begin{array}{l}25 \text { initiatives per year based on } \\
\text { industrial practice }\end{array}$ \\
\hline 4 & $\begin{array}{l}\text { Amount of potential energy savings } \\
\text { reviewed }\end{array}$ & $\begin{array}{l}15 \text { initiatives per year based on } \\
\text { previous years }\end{array}$ & $\begin{array}{l}25 \text { initiatives per year based on } \\
\text { industrial practice }\end{array}$ \\
\hline 5 & Initiatives translated into projects & $\begin{array}{l}\text { Five initiatives per year based on } \\
\text { previous years' experience }\end{array}$ & $\begin{array}{l}\text { Eight initiatives per year based } \\
\text { on industrial practice }\end{array}$ \\
\hline 6 & $\begin{array}{l}\text { Percentage of completed energy } \\
\text { performance benchmarking }\end{array}$ & $\begin{array}{l}\text { 70\% based on previous years' } \\
\text { experience }\end{array}$ & $\begin{array}{l}80 \% \text { based on industry best } \\
\text { practice }\end{array}$ \\
\hline 7 & Energy best practices issued. & $\begin{array}{l}\text { Two best practices annually as per } \\
\text { the previous history. }\end{array}$ & $\begin{array}{l}80 \% \text { based on industry best } \\
\text { practice }\end{array}$ \\
\hline 8 & $\begin{array}{l}\text { Percentage of implementation of } \\
\text { energy conservation initiatives }\end{array}$ & $\begin{array}{l}70 \% \text { based on previous years' } \\
\text { experience }\end{array}$ & $\begin{array}{l}80 \% \text { based on industry best } \\
\text { practice }\end{array}$ \\
\hline 9 & $\begin{array}{l}\text { Number of conducted training and } \\
\text { awareness }\end{array}$ & $\begin{array}{l}\text { Four events per years as per } \\
\text { previous years' experience. }\end{array}$ & $\begin{array}{l}\text { Five events per year based on } \\
\text { industry best practice }\end{array}$ \\
\hline 10 & Status of action items closure & $\begin{array}{l}70 \% \text { based on previous years' } \\
\text { experience }\end{array}$ & $\begin{array}{l}80 \% \text { based on industrial } \\
\text { practice }\end{array}$ \\
\hline 11 & Implementation progress of EnMS & $\begin{array}{l}\text { 80\% based on previous years' } \\
\text { experience }\end{array}$ & $\begin{array}{l}90 \% \text { based on industry best } \\
\text { practice }\end{array}$ \\
\hline
\end{tabular}

\section{Case Study - Implementation of Leading EnPI}

The above methodology of tracking the leading EnPI has been successfully implemented at one of the oil and gas companies referred to as Company X. The Company X's monitoring program involves six divisions, which are referred to A, B, C, D, E and F. Divisions are segregated according to specific tasks and location as per Table 7 . 
Table 7: Divisions' description

\begin{tabular}{|c|c|}
\hline Division & Description \\
\hline $\mathrm{A}$ & $\begin{array}{l}\text { The main function is to treat and process the raw gases to meet the power plants and } \\
\text { downstream requirements. This division consists of six gas treatment facilities }\end{array}$ \\
\hline $\mathrm{B}$ and $\mathrm{C}$ & $\begin{array}{l}\text { The main function of these two divisions is to provide oil, gas and water separation from raw } \\
\text { crude and gas wells. These two divisions are separated by demography. Both of these } \\
\text { divisions consist of five production facilities }\end{array}$ \\
\hline $\mathrm{D}$ & This is a downstream division that consists of six refinery and condensate splitters facilities \\
\hline $\mathrm{E}$ & $\begin{array}{l}\text { This division is dedicated to providing transportation of treated crude and gas from oil and } \\
\text { gas storage facilities to users and customers. This division consists of six facilities }\end{array}$ \\
\hline
\end{tabular}

Each division is made up of five or more facilities that apply to EnMS. At a defined interval, each of the concerned facility shall conduct a comprehensive self-assessment based on customised questionnaires to gauge the progress of its EnMS implementation against appropriate targets as defined by the corporate entity. The customised EnPI shall be based on an allocated weight for each of the major EnMS stages as per Deming quality cycle of PDCA where a certain weight to reflect the current needs of each concerned divisions have been given. The maximum weight of $100 \%$ will be allocated to a division that fully meets all agreed expectations. The allocation for PDCA may be different; for example, during the early stage of EnMS implementation, the PDCA stage will be given an equal weight of $25 \%$. However, as the program progress, the Do and Check will be given the highest weight. Once the program is matured, the Act stage will obtain the highest weight in order to ensure continuous improvement is fully embraced by the concerned divisions.

Table 8: The Company-X' leading energy performance indicator matrix

\begin{tabular}{|c|l|l|}
\hline Level & $\begin{array}{c}\text { Implementation } \\
\text { status }\end{array}$ & \multicolumn{1}{c|}{ Progress description } \\
\hline 0 & Entry-level & $\begin{array}{l}\text { EnMS is not implemented. There is no evidence to show that EnMS has } \\
\text { been implemented }\end{array}$ \\
\hline 1 & Preliminary level & $\begin{array}{l}\text { Major improvement gaps identified in all PDCA cycle as major steps of } \\
\text { EnMS defined in the ISO 50o01 (IPIECA, 2013a). }\end{array}$ \\
\hline 2 & Compliance level & $\begin{array}{l}\text { Meeting the minimum requirement of ISO 50001 standards (IPIECA, } \\
\text { 2013a). Addressed all major steps and some of the sub-steps of EnMS as } \\
\text { defined in Figure 3. }\end{array}$ \\
\hline 3 & Above compliance & $\begin{array}{l}\text { Fully compliance with ISO 50001 (IPIECA, 2013a). Addressed all major } \\
\text { steps and some of the sub-steps of EnMS as defined in Figure 3. }\end{array}$ \\
\hline 4 & Reference level & $\begin{array}{l}\text { Fully compliance with ISO 50001:2018 and becoming a reference } \\
\text { company. }\end{array}$ \\
\hline
\end{tabular}

In this case, study, since this is an early stage of EnMS implementation at Company-X, therefore all PDCA will be given equal weight. Subsequently, a set of questionnaires have been prepared to measure the implementation status of all concerned facilities against "compliance status" to meet the intent of EnMS' PDCA. EnMS progress measures are based on the second out of five levels of leading energy performance indicator matrix as per Table 8.

Questionnaires are randomly selected based on the main expectations from defined steps and sub-steps of ISO 50001 standards (Hassim et al., 2018) as illustrated in Figure 3. Selected questionnaires are listed in Table 9, and it will be 
completed by all concerned facilities. In order to improve the effectiveness of the assessment, all evidence is required to be furnished by all concerned facilities for reference. Results will be submitted to the concerned corporate entity for data validation, analysis, and followed by gaps identification.

Figure 4 shows an actual data of leading EnPI score by six divisions from the Company $\mathrm{X}$ against the minimum requirement of ISO 50001. Overall progress was 94\% toward meeting "compliance level" score. Each trend provides an indication of how well these business lines are in four categories; PDCA with equal weight (25\%) is allocated to each of the EnMS elements. The score indicated that the company has yet to meet the full expectations of ISO 50001, especially in the "Monitoring" and “Act" stages. Therefore, the comprehensive analysis shall be taken by the company to address the results, particularly on the performance monitoring on selected SEUs as well as finding ways on how to improve them.

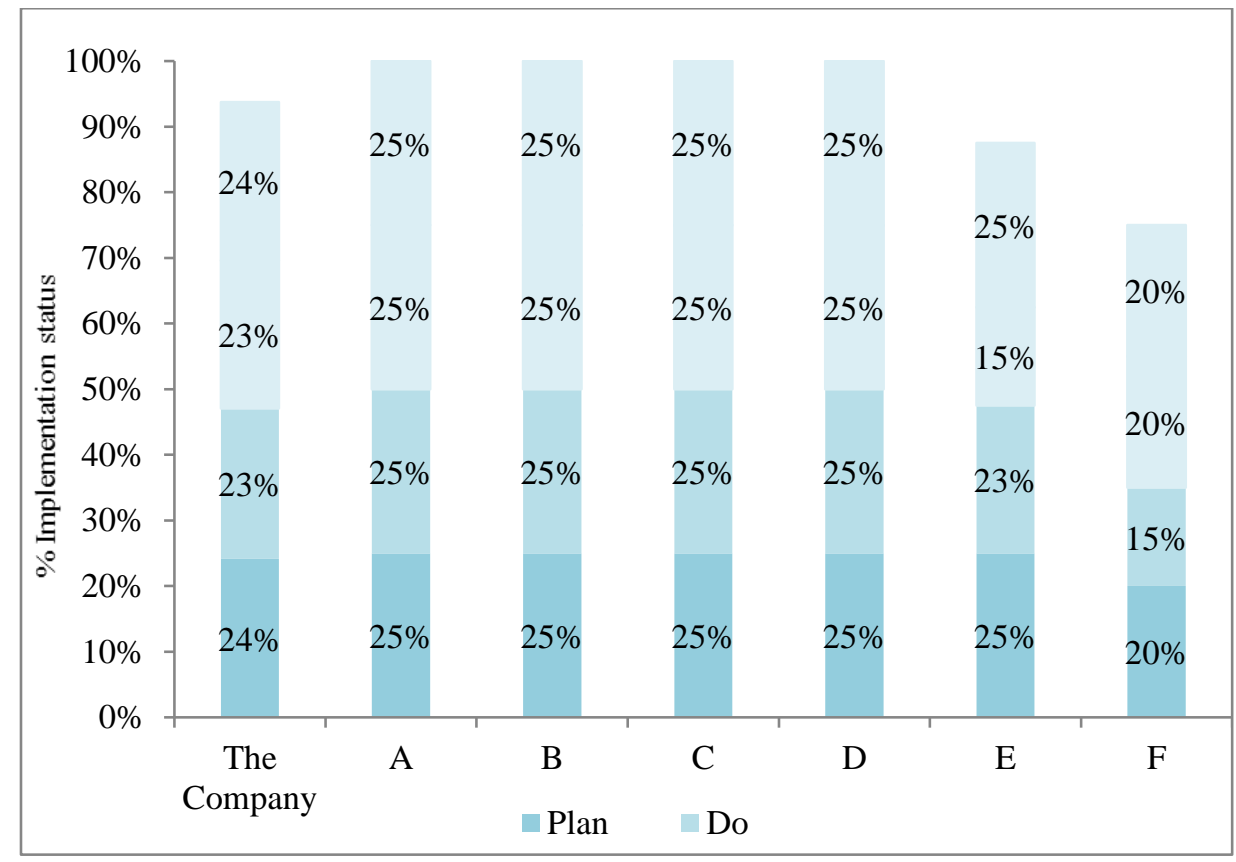

Figure 4: Leading Energy Performance Indicator for Company X

Table 9: Example of self-assessment questionnaires

\begin{tabular}{|c|c|}
\hline No. & Questions \\
\hline A & PLAN Step \\
\hline $\mathbf{1}$ & Has your management reviewed the energy policy in $2016 ?$ \\
\hline 2 & $\begin{array}{l}\text { Has your facility established a mechanism to gather energy improvement initiatives in the area of process } \\
\text { operation, maintenance, procurement, utilisation of electricity in plants, offices and for transportation? }\end{array}$ \\
\hline 3 & $\begin{array}{l}\text { Has your facility established criteria based on academic background, years of experience, training prior for } \\
\text { selection of energy coordinator? }\end{array}$ \\
\hline 4 & Has your facility addressed all steps and sub-steps of EnMS? \\
\hline 5 & Has your facility defined a sub-step to monitor its energy performance? \\
\hline 6 & Has your energy coordinator job description reviewed by management? \\
\hline B & DO Step \\
\hline
\end{tabular}




\begin{tabular}{|c|c|}
\hline 1 & Has your facility evaluated the need for an energy efficiency event? \\
\hline 2 & $\begin{array}{l}\text { Has each of identified energy initiative "contained in the Planned Energy Actions" been evaluated and } \\
\text { prioritised in accordance with documented criteria? }\end{array}$ \\
\hline 3 & Has your facility implemented energy plans as scheduled? \\
\hline 4 & Has your facility identified Significant Energy User (SEU) (unit/equipment/activity)? \\
\hline 5 & $\begin{array}{l}\text { Has your facility described mechanism to conduct root cause analysis (RCA) in the case that energy } \\
\text { objectives and targets were not met or any operational incidents? }\end{array}$ \\
\hline 6 & Has your facility measured the employees and contractors understanding on energy efficiency policy? \\
\hline $\mathbf{C}$ & CHECK Step \\
\hline $\mathbf{1}$ & $\begin{array}{l}\text { Has the energy performance of identified SEUs (unit/equipment/activity) been monitored, tracked and } \\
\text { controlled? }\end{array}$ \\
\hline 2 & Has an internal assessment been conducted this year? \\
\hline 3 & Has all critical energy metering devices been evaluated for accuracy and reliability? \\
\hline 4 & $\begin{array}{l}\text { Does your facility have an easily accessible and secure, consolidated documentation system in place, } \\
\text { adequately organised where all the relevant Energy Information is kept? }\end{array}$ \\
\hline $\mathbf{D}$ & ACT Step \\
\hline $\mathbf{1}$ & Has the status of energy plans implementation been updated to the management? \\
\hline 2 & Has the energy management review meeting been conducted this year? \\
\hline 3 & Has the EnPI performance and EnMS progress been updated to management? \\
\hline 4 & Has the facility identified performance measure of its EnMS? \\
\hline 5 & $\begin{array}{l}\text { Has management acknowledged the achievement related to EnMS to meet the company energy objectives } \\
\text { and targets? }\end{array}$ \\
\hline
\end{tabular}

\section{DISCUSSION}

This paper has recommended a novel methodology for leading EnPI that can provide each concerned oil and gas company with a snapshot of its EnMS implementation status against the agreed framework and meet the requirement of the internationally recognised EnMS. Its application is meant for future energy performance of any concerned company despite it not directly related to energy performance. Moreover, leading EnPI shall assist companies in monitoring the progress against the implementation objectives of EnMS or even any achievement made towards agreeable milestones. The leading EnPI tracks the implementation progress of EnMS against the desired intents and reflects the status of success or the success of an EnMS in which companies are deployed.

In the proposed methodology, the leading EnPI shall be established in a way to provide an overview of its continuous improvement progress toward becoming an excellent company in energy performance. Since achieving excellence is a journey; therefore, the progress of the journey shall be tracked using a customised EnPI. It shall be defined in a way that it supports and extends the idea of continuous improvement and promotes a strong partnership among employees, management, suppliers, customers, and the communities in which the company operates. In addition, EnPI shall be selected on its flexibility as well as effectiveness to drive in improving overall energy 
performance.

This EnPI shall be customised to monitor the implementation progress for dedicated EnMS steps and substeps. Several essential steps and sub-steps shall be tracked, including energy visions understanding, objectives and targets tracking, performance monitoring, competency training and opportunity identification. This EnPI has to be formulated to track continuous improvement tasks such as While selecting a leading driver's measure, it needs to match with the applicable company's defined objectives and targets. It is important to establish significant milestones of its EnMS and its baselines. Therefore, a realistic leading EnPI target shall be determined. Depending on selected leading EnPI, it may require performing activities such as series of data collection, interviews, assessments, desktop reviews, benchmarking exercises, data analysis and verification. Finally, conduct a performance review with the management can be carried out. Any feedback gathered from this review shall be used to improve the implementation of EnMS. In order to meet the intent of EnPI, which is focusing on simplification, practical and easy to implement, a simple measure of self-assessment needs to be selected and established.

The establishment of leading EnPI baselines and targets always depends on company approaches, alignment with company business plan and avoid any conflict with other strategies. Similarly, challenging EnPI targets shall be selected to enable the company to be on the right path of excellence which includes implementation of energy-saving initiatives in operational, quick fix and capital project. Benchmarking between the similar type of process within its sister companies or with external companies requires detail study as many factors can be considered.

\section{CONCLUSION}

This paper has concluded that a leading EnPI is a preferred tool for tracking the deployment and implementation status of EnMS at any concerned oil and gas company. Application of the proposed EnPI requires a systematic self-assessment method to ensure its effectiveness. The self-assessment method should be established as simple to administer and complete. gaining adequate support from companies, publishing of best practices, generating energy savings ideas, participating in $\mathrm{CoP}$, conducting training and engaging in other energyrelated activities. The customised EnPI shall be based on the allocated weight given to each of the major EnMS stages as per Deming quality cycle of PDCA to reflect current needs of each concerned company.

Dedicated efforts are required to ensure a fair presentation, independence and professionalism of the selfassessment outcomes. Through the determination of actual implementation progress against defined targets, therefore the factual status of EnMS implementation can be concluded. Methods for self-assessment may differ between organisations and whether it pertains to the high level, desktop or even detailed review including physical sites verification. Regardless which method has been deployed, it shall be performed with the intent to reveal the tangible drivers of improvement.

While developing the method to conduct self-assessment, a set of simplified self-assessment guidelines needs to be embedded into the method. The most important step is to appoint a competent person who can recognise EnMS implement gaps and can mitigate those gaps. As a quality check, a competent EnMS lead assessor should be engaged in this process and commented on the outcomes. In addition, dedicated computer programming models can be developed if applicable to minimise the subjectivity of the outcome and for document control purposes. The purpose of the programming is to find a sequence of instructions that will automate performing a specific task or solving a given problem. The process of programming often requires expertise in many different subjects, including knowledge of the application domain, specialised algorithms, and formal logic.

\section{ACKNOWLEDGEMENT}

The authors gratefully acknowledge the contribution from all involved parties for providing feedback on the application of leading energy performance indicator. 


\section{REFERENCES}

BASF 2013, Economic, environmental and social performance for 2013, BASF 2013 Annual Report, pp. 101. BP 2012, Energy Outlook 2030, British Petroleum (BP) Report, London, UK, pp. 52.

DNV 2015, Saving Energy Today for brighter tomorrow, View Point Report, DNV.GL. Norway.

Estes, J.M (eds) 2009, Smart Green: How to implement sustainable business practices in any industry - and make money, J. Wiley \& Sons, Inc., USA.

Energy Star 2016, Guidelines for Energy Management, United States Environment Protection Agency, USA.

ISO 500012018 , Energy management systems Requirements with guidance for use, International Organization for standardization, Switzerland.

ISO 50001 2015, A practical guide for SME - Energy Management System, International Standards Organization, Switzerland.

ISO 50006 2014, Energy Management SystemsMeasuring energy performance using energy baselines (EnB) and energy performance indicators (EnPI) General principles and guidance, International Standards Organization, Switzerland.

IPIECA 2013a, Guidelines for implementing ISO 50001 Energy Management System in Oil and Gas Industry, The global oil and gas association for environment and social issues Climate Change, London, UK.

IPIECA 2013b, Saving Energy in the oil and gas industry, The global oil and gas association for environment and social issues Climate Change, London, UK.

Imai, M (eds) 1986, Kaizen: The key for Japanese Competitive Success, McGraw-Hill Publishing Company, USA.
Kumana, J.D. and Sidhwa, N.R. 2009, 'Meaningful Energy Performance Metrics', in Proceedings of The Thirty-First Industrial Energy Technology Conference, New Orleans, USA.

Hassim M.H., Hashim, K.M. \& Ng D.K.S. 2018, 'Advancing Energy Performance in Oil and Gas Industry through Systematic Implementation of Energy Efficiency Programs by Applying an Operational Excellence Model', Journal of Energy \& Safety Technology, Vol. 1, No. 2, pp. 51-59.

Marcus, A. 2011, 'ICT and Eco-sustainability Working Group', in Proceedings for World Economic Forum, Davos, Switzerland, pp. 29.

Nuaim, A.S. 2019, 'One year of sustainability is not enough', Journal of Petroleum Technology, pp 10.

OECD 2015, An introduction to EnMS for Energy Savings and increased Industrial productivity for iron and steel sector, Directorate for science, technology and innovation steel committee, Organization for Economic Cooperation and Development, France.

Parmenter, D (eds) 2007, Developing, Implementing, and Using Winning KPIs, John Wiley and Son, USA.

Saudi Aramco 2015, Energy is opportunity, Annual Review 2015, Saudi Aramco Publication, Saudi Arabia.

Schuster, D 2015, 'Sustainability: What we can measure we can', Journal of Petroleum Technology, pp 14.

Shell 2013, Sustainability Report, Netherland, pp. 30.

Salomon 2013, Fuels and Refinery Performance Analysis, Salomon Associates, Page 1.

Tucker, RB (eds) 2002, Driving Growth through Innovation, BK Publishers, Inc., USA.

Trout, B 2012, 'Communities for a Better Environment, (eds) in Solomon Associates on Solomon Petroleum Refinery Efficiency Metrics for Creating a Level Playing 
Field in Benchmarking Energy and CO2 Performance, Richmond, USA, pp. 23.

The Arabian Sun 2014, Value Shaping our Culture and Appetite for Excellence, Saudi Aramco, Vol. 69, No. 6, pp. 1- 3.

The Arabian Sun 2015a, Operational Excellence Celebration, Saudi Aramco, Vol. 70 No. 22, pp. 3.

The Arabian Sun 2015b, Leading the Way to Excellence in Energy Efficiency, Saudi Aramco, Vol. 70, No. 4, pp. 4.

Turner, C.W 2001, Energy Management Handbook, 4th edn, The Fairmont Press, USA.

Vanner, R 2013, Energy Use in Offshore Oil and Gas Production; Trends and Drivers for Efficiency from 975 to 2025, PSI Working Paper, London, UK, pp. 2. 